\title{
THE ANALYSIS OF RELATIVE EFFICIENCY ON THE HOSPITALS OF THE TURKISH STATE UNIVERSITIES BY USING DATA ENVELOPMENT ANALYSIS (DEA) METHOD
}

\author{
Dr. Saadettin AYDIN1
}

\begin{abstract}
In this paper, the efficiency of the hospitals under the administration of state universities has been measured and evaluated by using DEA method between 1998-2000 in Turkey. In the first stage of the study, the structure of Turkish health-care system has been introduced in a brief way; input/output tables have been created. And empirical results have been summarized - by using EMS (Efficiency Measurement System) software, which is specially designed for academic users on a Compaq Presario 1700 P III, 128 MB Ram-through a table by presenting the DEA method that would be used for the solution of the problem. At the end of the study, some recommendations have been put forward for Turkish health-care system.
\end{abstract}

Keywords: Data envelopment analysis, linear programming, efficiency, health care system.

\section{Introduction}

Nearly half of the health expenditures in Turkey like other countries are made by hospital having beds. Therefore it is very important that whether this resources are used in productive and efficient way by hospitals which use much resources, Health sector that provides health care services with very limited resources has the only one tool which is using its resources very productively and efficiently in order to do its best and gets meaningful developments in health care indicators. However, studies on productivity measurement, control and development in Turkey are insufficient both in terms of quantity and quality.

Hospital services in Turkey are neither productive nor efficient comparing with developed countries. For example bed occupation rate is low, duration of stayed patient is long, and the rate of increase in the number of in-patient is lower than the rate of increase in the number of outpatient. Moreover, provided health care services are not at an acceptable level. Most of the registered patients do not get sufficient services. The main reason of this situation is the management problem. Furthermore the absence of regional hospitals and manpower planning, problems in training of personal, insufficient and unbalanced wage, various administrative practices of public hospitals that belong to different state organizations prevent their productive and efficient work.

Therefore increasing productivity is necessary in hospitals having bed that are very important in Turkey's health care system which is insufficient and also are insufficient number in Turkey by developing productivity measurement and control system and applications. This study aims to bring this reality to light by observing analysing and comparing university hospitals productivity results between 1998-2000 in Turkey.

\section{The Present Conditions in Turkey Health Care Services}

Ministry of Health (MH) has been founded in 1920 and continued organizing and modernizing the hospitals in towns and cities until 1960. Health care services has been included in 5 years plans for the first time by State Planning Organization (SPO) in 1960 and it has been started that hospitals must have run productively and efficiently in the fifth 5 years plan (SPO, 1988).

Health care sector in Turkey has rapidly been changing in accord with general tendencies in the world from the beginning after the year 1980. Developing policies and, practicing and providing health care services throughout the country is the duty of MH in Turkey. In 1988 Turkey has reorganized its public administration and constituted 81 provinces according to administrative and geographic criterions. The responsibility of productive and efficient use of the resources of health care services in provinces is the duty of city Health Care Directorates.

Health Care services in Turkey are provided by these organizations below

\footnotetext{
${ }^{1}$ University of Health Sciences, Gülhane Faculty of Medicine, saadettinaydin@gmail.com
} 
Public Sector

City Hospitals

Social Security Hospitals (Hospitals of Labour)

Military Hospitals

Chest Hospitals, Children Hospitals, Traffic Hospitals, Maternity Hospitals, etc.

Health Centres

University Hospitals

II) The Private Sector

Private Hospitals

Private University Hospitals

The half of the national health care expenditure are made by hospitals in all countries (Sochalski et al., 1997), $71 \%$ of the total health care expenditures is made by public health care organizations and $34 \%$ of this expenditure is made by MH in Turkey in 1996. 62\% of MH expenditures are made by hospitals. $63.4 \%$ of 1076 hospitals and $51 \%$ of 155819 beds in hospitals are belonging to the MH (Tokat, 1997).

The numbers of hospitals are increasing parallel to the growth in population year by year. For example the university hospitals that are studied were 29 in the year 1994 were 33 in the year 1998 and reached to 34 in the year 2000. The amount reserved for the health care services from the GNP takes an important place in raising the level of health care. This rate increased in developed countries by years while it decreased in Turkey from the $3.49 \%$ in the year 1981 to $2.98 \%$ in the year 1987 (MH, 1997).

\section{Productivity Measurement in Hospitals, DEA, Literature}

The concept of efficiency and its use as a management tool are quite new for hospitals. In order to evaluate the existing situation and take related necessary precautions to improve medical services, there should be an established efficiency. However, efficiency measurement system in hospitals is quite difficult. For this reason, it presents great importance what is meant by efficiency in medical services. It shouldn't be interpreted that increase in productivity of the hospitals can be reflected as on increase in examined, hospitalised and operated numbers of patients; or as an increase in the number of medical analysis, consumed medicines and given doctors' reports etc.

There are various approaches to the measurement of service productivity (Mc Loghlin and Coffey, 1990). Generally, three approaches are used to evaluate productivity, and these are followings: the most common are output/input ratios analysis, parametrical methods (statistical) and non-parametrical methods.

Firstly method has been used to locate relationship that is abnormally high or abnormally low. By in its nature, each ratio is limited to only one output and only one input, and it cannot easily accommodate situations in which multiple inputs are used to produce multiple outputs. Typically we take some output measure and divide it by some input measure. Note the terminology here; we view branches as taking inputs and converting them into outputs.

In the parametrical or econometric approach, the form of the production function is either assumed to be known or estimated statistically. Regression techniques reflect efficient relationship only when all the observation themselves are efficient. Regression techniques have been justified in industry studies, where profit maximization is believed to motivate all firms to operate at or near the efficient production frontiers. The third approach (as known deterministic methods) is non-parametric models. These methods are appropriate with mathematical programming (non-parametric) as a solutions technique including DEA.

However, because of the purpose of the application is to measure the relative efficiency of hospitals, which have the same decision making units, DEA is chosen.

Using engineering -like approach, Farrell (1957) attempted to measure the efficiency of a unit of production in the single input-single output case. Charnes, Cooper and Rhodes extended Farrell's idea and proposed a model that generalizes the single-input, single-output ratio measure of efficiency of a single DecisionMaking Unit (DMU) in multiple-inputs, multiple outputs setting.

Data envelopment analysis (DEA), occasionally called frontier analysis, was first put forward by Charnes, Cooper and Rhodes in 1978. It is a performance measurement technique can be used for evaluating the relative efficiency of decision-making units (DMU's) in organisations. To use DEA, the analysist must first 
identify a group of DMUs with similar organizational goals and similar management decisions. Variables are then identified that represent DMU inputs and outputs related to efficiency. Next, the inputs are modelled as a weighted average as are the outputs and the ratio is formed of outputs over inputs. In the solutions of DEA, the efficiency of unit is maximized subject to efficiencies of all the units in the set having an upper bound of 1 . The efficiency of the unit will either equal 1 when it is efficient relative to the other units or will be less than 1 when the unit it is inefficient.

The number of existing beds, the number of physicians (specialist and practitioner) are chosen as the inputs. On the other hand, five types of outputs determined are the number of out-patients, the number of inpatients, total patient days, the number of total operations (big, middle and small) and the number of deliveries.

Examples of such units for which DEA has been applied are the following: banks, police stations, hospitals (Sherman, 1984; Rosko, 1990, Miller and Adam, 1996, Al Shammari 1999, Sarkis and Talluri, 2002), tax offices, prisons, defence bases (army, navy, air force), schools and universities (Coelli, 1996; Athanassopoulos, 1997, Soteriou and et al., 1998, Abbot and Doucouliagos, 2001).

\section{Methodology}

The sample for this study covered all the 34 university hospitals (only 33 hospitals in1998) of the MH in Turkey between 1998-2000 years. The data upon which this work is based were obtained from the statistical report files of MH in it's web site (MH, 2003).

\begin{tabular}{|c|c|c|c|c|c|c|c|c|}
\hline $\begin{array}{l}\text { University } \\
\text { Hospitals }\end{array}$ & Years & $\begin{array}{c}\text { Numbe } \\
\text { r of } \\
\text { existing } \\
\text { bed }\end{array}$ & $\begin{array}{l}\text { Number of } \\
\text { physicians }\end{array}$ & $\begin{array}{l}\text { Number } \\
\text { of out- } \\
\text { patients }\end{array}$ & $\begin{array}{l}\text { Number } \\
\text { of in } \\
\text { patients }\end{array}$ & $\begin{array}{c}\text { Total } \\
\text { patient } \\
\text { days }\end{array}$ & $\begin{array}{l}\text { Number of } \\
\text { total } \\
\text { operation }\end{array}$ & $\begin{array}{l}\text { Number of } \\
\text { deliveries }\end{array}$ \\
\hline \multirow{3}{*}{ Cukurova Uni. } & 1998 & 286160 & 477 & 323923 & 22771 & 177475 & 11713 & 2161 \\
\hline & 1999 & 299665 & 376 & 328373 & 23274 & 234148 & 11248 & 1735 \\
\hline & 2000 & 300760 & 388 & 319844 & 24264 & 237406 & 12182 & 1996 \\
\hline \multirow{3}{*}{$\begin{array}{l}\text { Ankara Uni. } \\
\text { Cebeci }\end{array}$} & 1998 & 376315 & 195 & 207232 & 19229 & 254694 & 7106 & 1556 \\
\hline & 1999 & 388360 & 200 & 236858 & 20177 & 271620 & 7327 & 1685 \\
\hline & 2000 & 383250 & 201 & 247893 & 19784 & 269101 & 7364 & 1612 \\
\hline \multirow{3}{*}{$\begin{array}{l}\text { Ankara Uni. } \\
\text { İbni Sina }\end{array}$} & 1998 & 413180 & 517 & 205648 & 29126 & 352271 & 16084 & 0 \\
\hline & 1999 & 415005 & 517 & 193262 & 28425 & 357377 & 16443 & 0 \\
\hline & 2000 & 400405 & 498 & 193335 & 28827 & 347718 & 14870 & 0 \\
\hline \multirow{3}{*}{$\begin{array}{l}\text { Hacettepe } \\
\text { Uni. }\end{array}$} & 1998 & 332150 & 633 & 312134 & 25449 & 257369 & 9991 & 1649 \\
\hline & 1999 & 332150 & 630 & 255147 & 23473 & 253224 & 10334 & 1397 \\
\hline & 2000 & 332150 & 683 & 415206 & 22204 & 243674 & 9229 & 1198 \\
\hline \multirow{3}{*}{ Gazi Uni. } & 1998 & 291635 & 539 & 356302 & 24319 & 222583 & 10267 & 1343 \\
\hline & 1999 & 299300 & 537 & 385763 & 23109 & 260641 & 9451 & 1157 \\
\hline & 2000 & 293825 & 798 & 376654 & 21811 & 200599 & 9976 & 1694 \\
\hline \multirow[t]{3}{*}{ Akdeniz Uni. } & 1998 & 138335 & 423 & 164898 & 18968 & 129155 & 8659 & 1576 \\
\hline & 1999 & 140525 & 461 & 213925 & 21600 & 125607 & 10378 & 1400 \\
\hline & 2000 & 180675 & 530 & 265337 & 22945 & 149919 & 11004 & 1369 \\
\hline \multirow{3}{*}{$\begin{array}{l}\text { A. Menderes } \\
\text { Uni. }\end{array}$} & 1998 & 36500 & 109 & 87943 & 3740 & 2693 & 1876 & 34 \\
\hline & 1999 & 36500 & 177 & 94564 & 4511 & 28338 & 2494 & 58 \\
\hline & 2000 & 49640 & 231 & 109923 & 6274 & 31113 & 2989 & 189 \\
\hline \multirow{3}{*}{$\begin{array}{l}\text { Bolu İ.Baysal } \\
\text { Uni. }\end{array}$} & 1998 & 31025 & 52 & 41364 & 647 & 5116 & 386 & 0 \\
\hline & 1999 & 31025 & 82 & 54468 & 2044 & 14946 & 786 & 2 \\
\hline & 2000 & 31025 & 138 & 73383 & 2476 & 16563 & 1219 & 18 \\
\hline \multirow[b]{2}{*}{ Uludağ Uni. } & 1998 & 261340 & 413 & 357429 & 26022 & 189711 & 15059 & 1328 \\
\hline & 1999 & 278495 & 560 & 372647 & 26447 & 196193 & 16734 & 1183 \\
\hline
\end{tabular}


Uluslararası Ticaret ve Ekonomi Araştırmaları Dergisi Cilt: 4 Sayı: 1

\begin{tabular}{|c|c|c|c|c|c|c|c|c|}
\hline & 2000 & 285430 & 654 & 399351 & 29773 & 219283 & 15441 & 1024 \\
\hline \multirow{3}{*}{$\begin{array}{l}\text { Pamukkale } \\
\text { Uni. }\end{array}$} & 1998 & 35405 & 184 & 49952 & 2966 & 26189 & 1888 & 240 \\
\hline & 1999 & 41245 & 193 & 74788 & 4066 & 34368 & 2585 & 254 \\
\hline & 2000 & 43800 & 234 & 91013 & 4910 & 36488 & 2786 & 275 \\
\hline \multirow{3}{*}{ Dicle Uni. } & 1998 & 318280 & 466 & 232337 & 19525 & 182403 & 6630 & 1371 \\
\hline & 1999 & 337625 & 424 & 213387 & 22951 & 235038 & 7458 & 1366 \\
\hline & 2000 & 362080 & 451 & 203245 & 22476 & 218167 & 8718 & 1239 \\
\hline \multirow{3}{*}{ Trakya Uni. } & 1998 & 230680 & 352 & 224494 & 10415 & 135829 & 4317 & 446 \\
\hline & 1999 & 241995 & 399 & 191163 & 12012 & 143570 & 5010 & 659 \\
\hline & 2000 & 282875 & 148 & 198987 & 12717 & 133333 & 5168 & 624 \\
\hline \multirow{3}{*}{ Firat Uni. } & 1998 & 150380 & 253 & 176886 & 13922 & 109242 & 5188 & 1295 \\
\hline & 1999 & 157680 & 307 & 213655 & 17147 & 137389 & 7211 & 1244 \\
\hline & 2000 & 189800 & 339 & 189030 & 17886 & 151268 & 7556 & 1258 \\
\hline \multirow{3}{*}{ Atatürk Uni. } & 1998 & 321200 & 385 & 292167 & 23441 & 230160 & 6540 & 1501 \\
\hline & 1999 & 358430 & 427 & 319381 & 26945 & 254862 & 7445 & 1446 \\
\hline & 2000 & 358430 & 427 & 319381 & 26945 & 254872 & 7451 & 1446 \\
\hline \multirow{3}{*}{$\begin{array}{l}\text { Osmangazi } \\
\text { Uni. }\end{array}$} & 1998 & 291270 & 326 & 137308 & 17691 & 173781 & 6188 & 496 \\
\hline & 1999 & 288715 & 335 & 157276 & 19130 & 186386 & 7984 & 563 \\
\hline & 2000 & 289080 & 413 & 152453 & 11135 & 194875 & 8524 & 451 \\
\hline \multirow{3}{*}{ Anadolu Uni. } & 1998 & 28105 & 28 & 103853 & 2822 & 14348 & 1004 & 179 \\
\hline & 1999 & 27375 & 29 & 107647 & 2752 & 12218 & 965 & 193 \\
\hline & 2000 & 27375 & 28 & 115076 & 2453 & 11170 & 925 & 143 \\
\hline \multirow{3}{*}{ G.Antep Uni. } & 1998 & 51100 & 140 & 124430 & 6047 & 40095 & 3602 & 141 \\
\hline & 1999 & 51100 & 163 & 131603 & 6581 & 42797 & 3619 & 255 \\
\hline & 2000 & 80665 & 216 & 112982 & 5076 & 32188 & 2413 & 669 \\
\hline \multirow{3}{*}{ S.Demirel Uni. } & 1998 & 54625 & 139 & 110213 & 5719 & 41258 & 2914 & 40 \\
\hline & 1999 & 63875 & 165 & 121920 & 6695 & 49102 & 3169 & 101 \\
\hline & 2000 & 79935 & 226 & 105520 & 8523 & 60454 & 3722 & 120 \\
\hline \multirow{3}{*}{ Mersin Uni. } & 1998 & - & - & - & - & - & - & - \\
\hline & 1999 & 51830 & 124 & 92518 & 2268 & 15344 & 1208 & 2 \\
\hline & 2000 & 56940 & 185 & 118365 & 4841 & 46933 & 2237 & 9 \\
\hline \multirow{3}{*}{$\begin{array}{l}\text { Cerrahpaşa } \\
\text { Hosp. }\end{array}$} & 1998 & 644955 & 1068 & 380432 & 32973 & 446733 & 20299 & 1252 \\
\hline & 1999 & 625610 & 1042 & 374951 & 31842 & 441979 & 18963 & 1515 \\
\hline & 2000 & 585095 & 1067 & 363263 & 36235 & 424699 & 17234 & 1079 \\
\hline \multirow{3}{*}{ İstanbul Uni. } & 1998 & 573050 & 989 & 551920 & 34472 & 397086 & 17988 & 2492 \\
\hline & 1999 & 566115 & 968 & 709933 & 34226 & 430935 & 16031 & 2082 \\
\hline & 2000 & 566845 & 1054 & 594749 & 42689 & 536416 & 21923 & 2395 \\
\hline \multirow{3}{*}{ Marmara Uni. } & 1998 & 117165 & 304 & 124217 & 11209 & 67849 & 5455 & 478 \\
\hline & 1999 & 126290 & 303 & 115825 & 12383 & 102211 & 6598 & 571 \\
\hline & 2000 & 123005 & 303 & 172201 & 14274 & 118162 & 6425 & 510 \\
\hline \multirow{3}{*}{ Ege Uni. } & 1998 & 685105 & 592 & 594785 & 55208 & 495265 & 19972 & 1495 \\
\hline & 1999 & 666855 & 686 & 586895 & 52390 & 429180 & 20595 & 1503 \\
\hline & 2000 & 674155 & 848 & 558995 & 49331 & 429402 & 22116 & 1557 \\
\hline \multirow{4}{*}{$\begin{array}{l}\text { Dokuzeylül } \\
\text { Uni. }\end{array}$} & 1998 & 253310 & 726 & 357069 & 357795 & 208116 & 14181 & 481 \\
\hline & 1999 & 264260 & 796 & 378446 & 27227 & 218326 & 15849 & 598 \\
\hline & 2000 & 274480 & 862 & 399510 & 42969 & 231809 & 16508 & 757 \\
\hline & 1998 & 319740 & 425 & 204565 & 204990 & 249994 & 10628 & 2079 \\
\hline
\end{tabular}


Uluslararası Ticaret ve Ekonomi Araştırmaları Dergisi Cilt: 4 Sayı: 1

\begin{tabular}{|c|c|c|c|c|c|c|c|c|}
\hline \multirow[t]{2}{*}{ Erciyes Uni. } & 1999 & 383250 & 458 & 219958 & 27630 & 271517 & 11288 & 2005 \\
\hline & 2000 & 394565 & 491 & 211622 & 28344 & 280379 & 11383 & 1626 \\
\hline \multirow{3}{*}{ Kocaeli Uni. } & 1998 & 75920 & 269 & 106281 & 106550 & 51417 & 3022 & 480 \\
\hline & 1999 & 27375 & 295 & 118805 & 6096 & 47560 & 2047 & 462 \\
\hline & 2000 & 96725 & 320 & 128061 & 8057 & 58982 & 4028 & 504 \\
\hline \multirow{3}{*}{ Selçuk Uni. } & 1998 & 255500 & 328 & 248405 & 248733 & 218276 & 8536 & 2674 \\
\hline & 1999 & 310250 & 328 & 199141 & 19509 & 176449 & 6604 & 2240 \\
\hline & 2000 & 310250 & 543 & 222163 & 23526 & 235449 & 10177 & 2404 \\
\hline \multirow{3}{*}{ İnönü Uni. } & 1998 & 187610 & 280 & 144297 & 144577 & 117598 & 6497 & 859 \\
\hline & 1999 & 185785 & 297 & 148100 & 17835 & 167583 & 7863 & 999 \\
\hline & 2000 & 204035 & 343 & 153915 & 20042 & 187956 & 9453 & 1222 \\
\hline \multirow{3}{*}{ C. Bayar Uni. } & 1998 & 66430 & 238 & 92392 & 92631 & 36279 & 1988 & 114 \\
\hline & 1999 & 71540 & 258 & 97771 & 5882 & 46500 & 2815 & 281 \\
\hline & 2000 & 101835 & 304 & 114523 & 7484 & 56579 & 3144 & 337 \\
\hline \multirow{3}{*}{19 Mayıs Uni. } & 1998 & 271195 & 403 & 103695 & 104098 & 177335 & 6146 & 855 \\
\hline & 1999 & 286890 & 406 & 149288 & 19419 & 190754 & 6957 & 1104 \\
\hline & 2000 & 292975 & 338 & 169087 & 20045 & 202519 & 7118 & 1232 \\
\hline \multirow{3}{*}{$\begin{array}{l}\text { Cumhuriyet } \\
\text { Uni. }\end{array}$} & 1998 & 237250 & 223 & 84477 & 84700 & 149311 & 3560 & 210 \\
\hline & 1999 & 235060 & 239 & 107844 & 16821 & 189214 & 7420 & 518 \\
\hline & 2000 & 250390 & 278 & 107313 & 16730 & 187832 & 7298 & 345 \\
\hline \multirow{3}{*}{$\begin{array}{l}\text { Karadeniz } \\
\text { Uni. }\end{array}$} & 1998 & 177755 & 264 & 131641 & 131905 & 144917 & 6208 & 351 \\
\hline & 1999 & 177755 & 295 & 118015 & 14134 & 147556 & 6019 & 252 \\
\hline & 2000 & 179580 & 338 & 127890 & 14407 & 151579 & 6608 & 229 \\
\hline \multirow{3}{*}{ Harran Uni. } & 1998 & 34675 & 47 & 54155 & 54202 & 15860 & 1224 & 0 \\
\hline & 1999 & 37595 & 94 & 65301 & 2844 & 22337 & 1671 & 40 \\
\hline & 2000 & 65335 & 124 & 74541 & 3134 & 27017 & 1855 & 87 \\
\hline \multirow{3}{*}{ 100. Yil Uni. } & 1998 & 126655 & 216 & 117017 & 117233 & 77962 & 2350 & 598 \\
\hline & 1999 & 126655 & 211 & 117017 & 9182 & 77962 & 2350 & 598 \\
\hline & 2000 & 152570 & 225 & 151468 & 11605 & 100013 & 2783 & 1068 \\
\hline
\end{tabular}

Table I. Input/output data for MH hospitals in 1998, 1999 and 2000.

Certainly, the hospitals input and output are not composed of those. It has been got that some inputs and outputs which especially affect efficiency in a directly way from this paper.

Input types are the following:

The number of existing bed

The number of physicians

Outputs types are the following:

The number of out-patient

The number of in-patient

Total patient days

The number of total operations

(big, middle and small)

The number of deliveries. 


\section{The Model}

The model used in this study is the fractional and non linear DEA model which Charnes et al. have first developed: (A. Charnes et al, 1998)

(Input-Oriented CCR Primal)

(Output-Oriented CCR Primal)

$\left(\mathrm{CCR}_{\mathrm{p}}-\mathrm{I}\right)$

$\left(\mathrm{CCR}_{\mathrm{D}}-\mathrm{I}\right)$

$\min _{0, \lambda, s^{+}, s^{-}} z_{0}=\theta-\varepsilon \overrightarrow{1} s^{+}-\varepsilon \overrightarrow{1} s^{-}$

$$
\max _{\mu, v} \omega_{0}=\mu^{T} Y_{0}
$$

Subject to:

$$
\begin{array}{ll} 
& v^{T} X_{0}=1 \\
\text { s.t. } & \mu^{T} Y-v^{T} X \leq 0 \\
- & \mu^{T} \leq-\varepsilon \overrightarrow{1} \\
- & v^{T} \leq-\varepsilon \overrightarrow{1}
\end{array}
$$$$
\theta X-X \lambda-s^{-}=0
$$

$\lambda, s^{+}, s^{-} \geq 0$

where is $\overrightarrow{1} \lambda=1$.

This, in fact, was the linear programming formulation's optimisation: makes outputs maximized and inputs minimized. We will use the dual of this primal maximization model:

$$
\min . z=\sum_{1=1}^{m} x_{i j} a_{j}
$$

Subject to:

$$
\begin{aligned}
& \sum_{i=1}^{m} x_{i j} a_{j}-z x_{i} \leq 0 \quad(j=1,2,3, \ldots, n) \\
& \sum_{r=1}^{s} y_{r j} a_{j} \geq y_{r} \quad(j=1,2,3, \ldots, n) \\
& \sum_{j=1}^{n} a_{i j}=1 \\
& a_{j} \geq 0 \quad(j=1,2,3, \ldots, n)
\end{aligned}
$$

The notations of the formulation are :

$z \quad$ : efficiency score,

$x_{i j}$ : observed value of input i for hospital $\mathrm{j}$,

$y_{r j}$ : observed value of output $\mathrm{r}$ for hospital $\mathrm{j}$

$a_{j}$ : weights attached to input and output of hospital $\mathrm{j}$,

$x_{i}, y_{r}$ : inputs and outputs of the particular hospital whose efficiency is being evaluated (Al-Shammari, 1999).

\section{Model Solution}

It is a fact that in order to solve a DEA

problem, a computer and software, which can analyse 52 
the problem, are required. We used software, EMS (Efficiency Measurement Systems) which is freeware designed for academic users and this program was run by a standard PC (Compaq Presario, P III, 128 RAM).

\section{Empirical Results}

We had EMS software run by loading data files, therefore the relatively efficiency scores have been summarized with a table below belonging to 1998-2000. The score column displays the relatively efficiency value, and the rank column displays the order of the relatively inefficiency value among the hospitals compared in their own years. The score's being equal to 1 identifies the relatively efficiency, and its being smaller than 1 identifies the relatively inefficiency. The more the value decreases, the more the inefficiency increases.

\begin{tabular}{|c|c|c|c|c|c|c|c|}
\hline \multirow[b]{2}{*}{ No. } & \multirow{2}{*}{$\begin{array}{l}\text { University } \\
\text { Hospitals }\end{array}$} & \multicolumn{2}{|c|}{1998} & \multicolumn{2}{|c|}{1999} & \multicolumn{2}{|c|}{2000} \\
\hline & & Score & Rank & Score & Rank & Score & Rank \\
\hline 1 & Cukurova & 1 & 1 & 1 & 1 & 1 & 1 \\
\hline 2 & Ankara Cebeci & 1 & 1 & 1 & 1 & 1 & 1 \\
\hline 3 & Ankara İbni Sina & 1 & 1 & 1 & 1 & 1 & 1 \\
\hline 4 & Hacettepe & 0,949 & 4 & 0,912 & 6 & 0,983 & 4 \\
\hline 5 & Gazi & 0,990 & 3 & 1 & 1 & 1 & 1 \\
\hline 6 & Akdeniz & 1 & 1 & 1 & 1 & 1 & 1 \\
\hline 7 & A. Menderes & 0,991 & 2 & 1 & 1 & 1 & 1 \\
\hline 8 & Bolu İ.Baysal & 0,906 & 7 & 0,882 & 8 & 1 & 1 \\
\hline 9 & Uludağ & 1 & 1 & 1 & 1 & 1 & 1 \\
\hline 10 & Pamukkale & 1 & 1 & 0,931 & 3 & 1 & 1 \\
\hline 11 & Dicle & 0,677 & 19 & 0,871 & 10 & 0,776 & 13 \\
\hline 12 & Trakya & 0,743 & 15 & 0,685 & 15 & 1 & 1 \\
\hline 13 & Firat & 0,8968 & 9 & 1 & 1 & 1 & 1 \\
\hline 14 & Atatürk & 0,8974 & 8 & 0,949 & 2 & 0,978 & 5 \\
\hline 15 & Osmangazi & 0,738 & 16 & 0,829 & 11 & 0,770 & 14 \\
\hline 16 & Anadolu & 1 & 1 & 1 & 1 & 1 & 1 \\
\hline 17 & G.Antep & 1 & 1 & 1 & 1 & 1 & 1 \\
\hline 18 & S.Demirel & 1 & 1 & 0,910 & 7 & 0,916 & 8 \\
\hline 19 & Mersin & - & - & 0,545 & 16 & 0,996 & 3 \\
\hline 20 & Ist. Cerrahpaşa & 1 & 1 & 1 & 1 & 0,961 & 6 \\
\hline 21 & İstanbul & 1 & 1 & 1 & 1 & 1 & 1 \\
\hline 22 & Marmara & 0,717 & 18 & 0,914 & 5 & 1 & 1 \\
\hline 23 & Ege & 1 & 1 & 1 & 1 & 1 & 1 \\
\hline 24 & Dokuzeylül & 1 & 1 & 1 & 1 & 1 & 1 \\
\hline 25 & Erciyes & 0,932 & 6 & 1 & 1 & 1 & 1 \\
\hline 26 & Kocaeli & 0,795 & 12 & 1 & 1 & 0,866 & 10 \\
\hline 27 & Selçuk & 1 & 1 & 1 & 1 & 1 & 1 \\
\hline 28 & İnönü & 0,782 & 13 & 1 & 1 & 1 & 1 \\
\hline 29 & C. Bayar & 0,640 & 20 & 0,687 & 14 & 0,724 & 15 \\
\hline 30 & 19 Mayıs & 0,758 & 14 & 0,778 & 12 & 0,829 & 11 \\
\hline 31 & Cumhuriyet & 0,829 & 11 & 1 & 1 & 0,960 & 7 \\
\hline 32 & Karadeniz & 0,948 & 5 & 0,921 & 4 & 0,911 & 9 \\
\hline 33 & Harran & 0,866 & 10 & 0,876 & 9 & 0,779 & 12 \\
\hline 34 & 100. Yıl & 0,732 & 17 & 0,742 & 13 & 0,999 & 2 \\
\hline
\end{tabular}

Table II - Summary of DEA efficiency scores and rating for MH hospitals (1998-2000) 
Totally 33 hospitals have been evaluated in 1998. 14 of those evaluated hospitals $(1,2,3,6,9,10,16,17,18,20,21,27)$ are efficient and the other 19 hospitals are inefficient. As a result, C.Bayar University (indicated with 29) has the lowest score with 0,640 value in that year. This hospital were able to use 63,95 per cent of its sources, or were not able to use 36,05 per cent of each input meaning the inefficient resource usage and idle capacity. The scores of inefficient hospitals vary between $(0,640-0,991)$. Inefficiency of resource usage and existence of idle capacity was striking. That any contribution would be made is said to be a matter of resource loss.

Data for 34 hospitals was analysed in 1999. 19 of those hospitals $(1,2,3,5,6,7,9,13,16,17$, $20,21,23,24,25,26,27,28,31)$ are efficient and the other 15 hospitals $(4,8,1011,12,14,15,18,19,22,29,30,32,33,34)$ are inefficient. As a consequence, the number of those efficient had been increased about $27 \%$-five hospitals are added this year- since 1998. Mersin University (19th), taking part in the set for the first time, listed as the lowest one in the column of inefficient with the score 0,544. Despite being efficient the year before, 10 and 18 th hospitals are inefficient in 1999. On the other hand, 5,7,13,25,26,31th hospitals are inefficient in 1998, yet they are efficient the year after. The scores of inefficient hospitals vary between 0,545-0,949.

In 2000, 20 of 34 hospitals $(1,2,3,5,6,7,8,9,10,12,13,16,17,21,22,23,24,25,27,28)$ are identified as efficient in the table. The rest of them, 14 hospitals $(4,11,14,15,18,19,20,26,29,30,31,32,33,34)$ are relatively inefficient.

C. Bayar University Hospital, with a 0,724 score, become the least inefficient hospital in this year, too as it did in 1998. The scores of inefficient hospitals vary between $(0,724-0,999)$.

When the Table II and the commentaries on it evaluated together, we can get the results table below:

\begin{tabular}{|l|c|}
\hline Hospitals relatively efficient during a three-year period. & $1,2,3,6,916,17,21,23,24,26$ \\
\hline Hospitals relatively inefficient during a three-year period. & $4,11,14,15,29,30,32,33,34$ \\
\hline $\begin{array}{l}\text { The ones only relatively efficient during a two-year } \\
\text { period. }\end{array}$ & $5,7,10,13,25,28$ \\
\hline \begin{tabular}{l} 
The ones only relatively efficient during one year period. \\
\hline
\end{tabular} & $12,18,22,26,31$ \\
\hline
\end{tabular}

Table III - The table of relative efficiency for different periods.

\section{Results and Recommendations}

With relative productivity analysis performed -by using DEA method- on the hospitals of Republic of Turkey, it was aimed to determine the levels of input used excessively by the hospitals relatively productive or by the hospitals found unproductive, and to determine the level of service which could not be rendered by these hospitals in a sufficient level of quality. Accordingly, the level of productivity was fixed as X\% between 1998-2000. It was determined that the basic and the fundamental reason for such unproductiveness is that the excessive inputs caused by the unplanned investments are put in service with an idle capacity and that the services rendered are insufficient.

\section{We can arrange the analysis results in the following order:}

- The hospitals that are relatively productive became productive by producing and rendering the services more than the hospitals that are relatively unproductive.

- Geographical development and positioning near-centre in respect of productivity-unproductiveness do not cause a considerable difference.

- $\quad$ Although the current numbers of beds and the doctors of the hospitals that are relatively unproductive are same with the other departments, they could not use a sufficient capacity in polyclinic and surgery services.

- The hospitals that are relatively unproductive had not been chosen the way to reduce their unproductiveness level by decreasing the number of inputs, they use excessively, for the next year. 
- In the hospitals unproductive and operating with full capacity, input purification does not carried out. Since the increase in service demand was not considered, relative unproductiveness score has decreased more in some sections as the result of the fact that same number of inputs has been used to meet more service demand.

- After the determination of relative productive and unproductive hospitals by using DEA method, it can be saw that the results have been confirmed based on the rational values of all data, achieved by a simple calculation.

- When the relatively productive hospitals are compared to the ones that are relatively unproductive in respect to input/service variables, the difference between the averages depending on the model used is statistically meaningful. It can be said that the hospitals that are unproductive over the years has yielded/rendered less service by using more inputs.

By taking above-mentioned results into consideration, the following recommendations can be put forward for Turkish health system:

- Health methodology programs, fit for productivity principles, able to use insufficient sources rationally, and comprising modern administrative/management sciences must be developed for the health services.

- $\quad$ Faster and more efficient results can be achieved by offering DEA - relative productivity measurement method that is a modern productivity measurement method to the responsible personnel in hospitals' statistic bureaus after training them about this method. Therefore, productive/unproductive departments inside the hospital can be detected once in each three months, and consequently the source usage can be arranged a few times according the months and seasons changing during a year. By this application during a few periods or years, stochastic analyses are possible to carry out after deterministic results are obtained.

- The input achievement can be ensured by transferring the inputs (idle capacity usage) stored/maintained in the hospitals that are unproductive to the hospitals trying to meet the demands over its capacity.

- It has been known that the statistical results related to studies about the hospitals do not certainly show the reality due to structural problems caused by the structure of Turkish health system. Consequently, planning and source assignment transactions carried out after evaluation of such data since the results are generally given in complete will not show the reality. That's why, after the researchers are provided with the actual and completely correct statistical data, the researchers will be able to offer and give the results that will make strategic decision-making easy for the hospital managers and the committees making health service planning.

- The hospital charges must be adjusted in accordance with the real costs and the general economical situation that the home country currently has. For that reason, the hospital managers must be powered with all of management and supervision powers/authorities. Unproductive hospitals can be made effective by activating the idle sources, which is ensured by adjusting the prices/charges.

- Being a research and education hospital does not necessitate for university hospitals to work and operate unproductively. A hospital must base management perception on the productivity basis in order to keep the works going on. It must be noted that the students taking medical education, research personnel, and the students of nurse and health high schools are the factors than can considerably affect the input since they have been studying/working in the hospitals during a specific period of their education. It is a real that unproductiveness scores will decrease more by taking these factors into consideration in a productivity analysis study in which all the inputs will be evaluated by a more detailed study.

- Regarding the national profitability, it is impossible to tell about the loss on general budget caused by the unproductive hospitals compared to the ones that are productive since a financial analysis is not carried out. Moreover, the unproductiveness of some hospitals that receive surgery room and laboratory services less or not at all will be more positive compared to other group in respect to general profitability. 


\section{REFERENCES}

- Abbot, M. and Doucoulagos, C.,(2003), The Efficiency of Australian universities; a data envelopment analysis, Economics and Education Review Vol. 22,pp.89-97.

- Al-Shammari, M.(1999), "A multi-criteria data envelopment analysis model for measuring the productive efficiency of hospitals", International Journal of Operations \& Production Management; Vol.19 No. 9, pp.879-90.

- Athanassopoulos, A., \&Shale, E., (1997), "Assessing the comparative efficiency of higher education institutions in the UK by means of data envelopment analysis", Education Economics, Vol.5 No.2, pp.11734.

- Charnes, A., Cooper, W., Lewin, Y. and Seiford., L.M. (1998), Data Envelopment Analysis: Theory, Methodology, and Application, Kluwer Academic Publishers, USA..

- Charnes, A. Cooper; W. and Rhodes, E.,(1978), "Measuring the efficiency of decision making units", European Journal of Operations Research, Vol.2, No.6, pp.429-44.

- Coelli, T. (1996a), Assessing the performance of Australian universities using data envelopment analysis, Mimeo. Center for Efficiency and Productivity Analysis, University of New England.

- Farrell, M.J. (1957), "The measurement of productive efficiency", Journal of Royal Statistical Society, Series A, Vol. 120 No.3, pp.253-81.

- McLaughlin, C.P. and Coffey, S. (1990), "Measuring productivity in services", The International Journal of Services Industry Management, Vol. 1 No.1, pp.46-64.

- Miller, J.L., and Adam Jr.E.E. (1996), "Slack and performance in health care delivery", International Journal of Quality and Reliability Management, Vol. 13 No. 8, pp.63-74.

- Ministry of Health, (1997), The Annual Statistical Report of Health Care Organizations,. Ministry of Health Publications, No. 599, Ankara, Turkey.

- Ministry of Health, (2003), www.saglik.gov.tr, access date 12.01.2003.

- Rosko, M.D. (1990), "Measuring technical efficiency in health care organizations", Journal of Medical Systems, Vol.14 No.5, pp.307-21.

- Sarkis, J., Talluri, S., (2002), "Efficiency measurement of hospitals: issues and extensions", International Journal of Operations \& Production Management; Vol. 22, No. 3, pp.306-13.

- Sherman, H. (1984), "Hospital efficiency measurement and evaluation: empirical test of a new technique", Medical Care, Vol.22 No.10, pp.922-38.

- Sochalski, J Aiken LH, Fagin CM (1997), “Hospital Restructuring in the United States, Canada, and Western Europe, An Outcomes Research Agenda", Medical Care, 35(10):0S13.

- Soteriou, A.C., Karahanna, E., Papanastasiou, C., Diakourakis, M., (1998), "Using DEA to evaluate the efficiency of secondary schools: the case of Cyprus", International Journal of Educational Management; Vol. 12 No. 2, pp.65-73.

- Turkish State Planning Organization, (1988), Pub. No: 2065, Ankara, Turkey.

- Tokat, M., (1997) Turkish Health Finance and Expenditures (1992-96), Health Projects Coordinators, MH Publications, 1997, Ankara, Turkey. 